\title{
THE BLIZZARD OF THE WORLD: COVID-19 AND THE LAST SAY OF THE STATE OF EXCEPTION
}

\begin{abstract}
The paper aims to grasp the COVID-19 pandemic as a socio-political catastrophe in the Benjaminian sense. As argued in the article, the scope and nature of the COVID-19 crisis eludes us due to our closeness to its inner core. What is obfuscated in this moment is the politico-legal framework on which the international community is based, where sovereignty and turbocapitalism join their forces to produce biopolitical devices. The paper looks into uses of the state of exception in particular countries, concluding that the rule of law in the pandemic was generally put on the back burner even by the countries that officially praise it. Sovereignty clearly returned to the stage, undermining parliamentarism and civil liberties in the sake of necessity. International law remained incapable of addressing this return, let alone of enforcing responsibility of China for infringing WHO rules. As a conclusion the paper argues that COVID-19 opened new-old paths of governing the living that will play a planetary role in the future fights for dominance and imposing a new face of capitalism.
\end{abstract}

Keywords: COVID-19, state of exception, biopolitics, sovereignty, necessity.

\section{ZADYMKA ŚWIATA: COVID-19 I OSTATNIE SŁOWO STANU WYJĄTKOWEGO}

Streszczenie. Celem artykułu jest ujęcie pandemii COVID-19 jako socjopolitycznej katastrofy w sensie Waltera Benjamina. Zakres i natura kryzysu związanego z COVID-19 są nam niedostępne z racji naszej bliskości do jego centrum. W tym szczególnym momencie zaciemnieniu ulegają polityczno-prawne ramy wspólnoty międzynarodowej, w których suwerenność i turbokapitalizm łączą się w celu stworzenia biopolitycznych urządzeń. W artykule dokonano przeglądu zastosowań stanu wyjątkowego w poszczególnych państwach; jego konkluzją jest ogólne zaniedbanie kwestii praworządności nawet w krajach, które głoszą do niej przywiązanie. Bez wątpienia kluczową rolę zaczęła ponownie odgrywać suwerenność - podważając parlamentaryzm oraz swobody obywatelskie w imię konieczności. Prawo międzynarodowe okazało się niezdolne nie tylko do odpowiedzi na to zjawisko, ale nawet do wyegzekwowania odpowiedzialności Chin za złamanie reguł WTO. Artykuł zamyka konkluzja, zgodnie z którą COVID-19 otworzył nowe-stare ścieżki zarządzania żywymi, które odegrają planetarną rolę w przyszłych walkach o dominację i przeobrażą funkcjonowanie kapitalizmu.

Słowa kluczowe: COVID-19, stan wyjątkowy, biopolityka, suwerenność, konieczność.

${ }^{*}$ Nomos: Centre for International Research on Law, Culture and Power, Jagiellonian University in Kraków; przemyslaw.tacik@gmail.com 


\section{INTRODUCTION}

Identifying Kafka as an essentially contemporary writer, Walter Benjamin made the following claim about the possibility of perceiving the catastrophe:

If one says that he perceived what was to come without perceiving what exists in the present, one should add that he perceived it essentially as an individual affected by it. His gestures of terror are given scope by the marvellous margin which the catastrophe will not grant us. But his experience was based solely on the tradition to which Kafka surrendered; there was no farsightedness or "prophetic vision." Kafka listened to tradition, and he who listens hard does not see. (Benjamin 1969a, 143)

The perception of the catastrophe not as a singular event, but as the permanent essence of the development of history is of course a key to Benjamin's latest version of historical materialism (Benjamin 1969b, 257). But in the above-cited fragment he rather links the ability to perceive a catastrophe with the possibility of occupying some "marvellous margin". Kafka was able to notice the catastrophe precisely because he was immersed in (Jewish) tradition. By this very fact he was sensitive to apocalyptic sounds coming from afar, just like the people of Israel who listened to the godly voice; but between him and the catastrophe lay the margin that - Benjamin adds - won't be "granted" to us. "We" see the catastrophe from too close a distance, experiencing it in all its impact, and without the mediation of the tradition that would shield it from us.

The COVID-19 pandemics is one catastrophe among others, another link in the chain of "anthropocenic" troubles that late capitalism keeps producing. It is particularly legal scholarship that should see it as another stage in the continuous catastrophe that reels before our eyes - and not a one-off break in the otherwise continuous normalcy that will be soon restored. Yet the Benjaminian trouble affects us as well: our tradition - especially the legacy of Schmittianand Agambenian thinking on the state of exception - allows us to hear, but not see. When we occupy "the marvellous margin" we are blind, but at the same time the catastrophe is already here, before our eyes. To see the current pandemic - in its legal dimension - as a mere recurrence of exception-based measures is to say too little; but without this perspective we see just the catastrophe, without knowing its nature.

Accordingly, the already considerable COVID legal scholarship straddles between hearing and seeing. In this position, it can hardly make a move, as the key to our riddles lies ahead of us. With the benefit of the $20^{\text {th }}$ century legal and philosophical thinking we can easily recognise the contours of what is happening: but at the same time the recurrence of states of exception, priority of the executive over the legislative and the judiciary, sovereign-centrism, mobilisation of populist reason against democracy is painfully sobering. It does not mean that these concepts and the intellectual traditions that inform them are useless; on the 
contrary, they allow us to hear the ongoing catastrophe, but do not form a bridge with our position of seeing it.

In its legal dimension, COVID-19 could be used as a palpable example of Luhmann's theory of autopoietic systems (Luhmann 2004): each state reacted to it according to its own internal dynamics and systemic specificity. Although some general patterns were recognisable in many countries (lockdowns, increase in penal reactions, priority of the executive, extraordinary legislation, national segregation), they were introduced with the use of various methods, each time according to the internal logic of Leibnizian monads. The adopted measures demonstrate, first of all, the possibility of suspending some basic liberal guarantees; what remains striking is the swiftness with which they were implemented, often without a clear link with diminishing the medical emergency. The sovereign state has always been here and the return of the state of exception may only prove the proponents of the post-Westphalian order wrong. Its return cut across the current political episteme that today make us see the political scene as divided between the significantly undermined liberal order and the populist onslaught on reason: legal criticism of emergency measures ran the risk of being identified with unreason indulging in conspiracy theories.

Nonetheless, the greatest conspiracy theory we could think of is clearly visible for our eyes: the nature of currently existing states - with their extraordinary politico-legal weaponry behind their backs - squares well with contemporary capitalism and is not on the wane. For financial markets the year 2020 was astonishingly profitable, whereas the almost universal recession will throw masses of people into the conditions of yet bigger poverty and dependence (Bohoslavsky 2020). State power is on the rise, methods of control have been tested out. Legal scholarship on COVID is on the mount, dealing with issues as diverge as the fate of legal professions and economic consequences of the pandemic, but focusing on constitutionality of the adopted measures.

This paper will venture a risky attempt of passing from hearing to seeing the catastrophe, whose impact and scope are still unclear to us. First, I will reanalyse the concepts of necessity and exception, in their link with specific responses to COVID-19. Then I will address the practical differences in handling the pandemic by liberal and illiberal states. Finally, I will take a quick detour to international law in order to look at its possible responses to COVID.

\section{SNEAKY NECESSITY AND THE OVERWHELMING EXCEPTION}

In Kazuo Ishiguro's recent novel, The Buried Giant, protagonists live in a post-war period under some kind of spell which make them forget about past feuds. Their memory is eclipsed with a mist of forgetfulness that brings peace for the sake of helpless oblivion. The current pandemic produces a comparable kind 
of mist: we are willing to rake out exceptional measures as if the feuds and wars to which their use lead in the past were shrouded by forgetfulness.

The pandemic is presented as an enemy, but a sneaky one: ubiquitous, hard to detect and constituting a special kind of necessity. Nonetheless, legally speaking, this necessity eludes the distinction between external and external threat. In the early phases of the pandemic, it came from abroad everywhere but China - just as a classic external enemy against whom putting up fences and closing borders should be adopted. In this phase, the pandemic unleashed a sovereigntist and nationalist logic: borders were closed for all except citizens and permanent residents, air connections were shut down, 'repatriation' actions were undertaken. The lockdown was conducted in the sovereign-centred manner; the states proved that true sovereignty lies in the ultimate power of suspension (cf. Schmitt 1985, 5; Agamben 2005). The globally recognised necessity allowed the states to suspend freedom of travel without much resistance at the international level. March 2020 was a period of universal national contraction, in which freedoms proved nothing but temporary concessions from sovereignty. In this role, sovereign states positioned themselves as the ultimate interpreters of necessity. Even if COVID-19 seems to impose - from an epidemiological point of view - a chain of typical reactions (shutdown of trade, travel and movement), it is up to the sovereign power to decide on what the necessity really is. Apart from the medical emergency, there is also another kind of necessity that needs to be balanced with the COVID: economy. The dilemma of which goal to pursue: healthcare protection or economic development was decided by sovereign powers (Bohoslavsky 2020), and obviously not in order to avoid the situation in which the crisis hits the most vulnerable members of the society. The sovereign choice shrouds inequality - in its many dimensions, from economic differentiation to gender inequality (Bohoslavsky 2020) - with the aura of unquestionability.

"How it ultimately should be": that a kind of thinking that unites, at the deepest level, sovereignty and health emergency. In its reactions to autonomously defined necessity, states resorted to the classic logic of nationalism (in Anderson's and Billig's understandings - see Anderson 1991; Billig 1995) against health reasons: they admitted their own citizens from abroad, but denied access to foreigners just as if its 'own' citizens had posed less danger than all other people. Even if nowadays these measures seem to be just groping in the dark, without the full knowledge of how COVID works, it should be properly seen as an ominous sign: a possibility of resolving the questions of necessity, regardless of its nature, along the lines of the old nationalist and sovereigntist logic. Diversity of state reactions posed practical problems for people travelling across many countries, sometimes barring their way of return. In so doing, states revealed an intimate relationship between sovereignty and citizenship which might be omitted if we concentrate - after Agamben - on the biopolitical status of bare life. By 
recalling their citizens from the entire world and barring access to non-citizens states demonstrated the tight link between inclusion and exclusion that founds citizenship. Analogously to structuralist understanding of the signifier as drawing meaning from a web of negative relations to other signifiers, citizenship proved to be a right to be admitted due to everyone else's exclusion.

The chain of entanglements that binds sovereignty and citizenship should be confronted with another one: the relationship between sovereignty and the executive. As diagnosed already by Schmitt (Schmitt 1988), the executive exhibits proneness to overtaking other state powers in times of emergency, most notably by eclipsing parliamentarism. In constitutional theory parliamentarism requires as its prerequisites freedom of speech, freedom of discussion and the general public that can influence the decision-making process.

All specifically parliamentary arrangements and norms receive their meaning first through discussion and openness. This is especially true of the fundamental principle that is still recognized constitutionally, although practically hardly still believed in today, that the representative is independent of his constituents and party; it applies to the provisions concerning freedom of speech and immunity of representatives, the openness of parliamentary proceedings, and so forth. These arrangements would be unintelligible if the principle of public discussion were no longer believed in (Schmitt 1988, 3).

In an almost Badiouian manner, the parliament is for Schmitt a locus of truthproduction which, as soon as colonised by technical expertise - not even by an open dictatorship, but by dominance of the executive, ceases to exist truly:

If parliament should change from an institution of evident truth into a simply practical-technical means, then it only has to be shown via facta, through some kind of experience, not even necessarily through an open, self-declared dictatorship, that things could be otherwise and parliament is then finished (Schmitt 1988, 8).

According to Schmitt, mass democracy throws parliamentarism into a specific crisis which amplifies, but is not equivalent to, the crisis of democracy as such:

The crisis of the parliamentary system and of parliamentary institutions in fact springs from the circumstances of modern mass democracy. These lead first of all to a crisis of democracy itself, because the problem of a substantial equality and homogeneity, which is necessary to democracy, cannot be resolved by the general equality of mankind. It leads further to a crisis of parliamentarism that must certainly be distinguished from the crisis of democracy. Both crises have appeared today at the same time and each one aggravates the other, but they are conceptually and in reality different. As democracy, modern mass democracy attempts to realize an identity of governed and governing, and thus it confronts parliament as an inconceivable and outmoded institution. If democratic identity is taken seriously, then in an emergency, no other constitutional institution can withstand the sole criterion of the people's will, however it is expressed. Against the will of the people especially an institution based on discussion by independent representatives has no autonomous justification for its existence, even less so because the belief in discussion is not democratic but originally liberal. (Schmitt 1988, 15) 
In other words, the position of the parliament as the embodiment of the will of the people is no longer taken for granted. Sovereignty might be - and, practically, is - exercised in its true locus that is revealed in the state of emergency. Accordingly, in the pandemic the balance of state powers was profoundly disturbed in a multidimensional way. Many states drifted far from the pole connoting parliamentarism, open discussion, human rights and inclusion of individuals - towards the pole that concentrates opposite paradigms: priority of the executive, secret decision-making (often explained away with the authority of experts, even though the way from acknowledging experts' recommendations to adopting particular measures is not only long, but most importantly, political), suspension of applicable human rights and exclusion of individuals through the category of citizenship. It is in this last aspect that the profoundly political nature of response to COVID was palpable: it would be absurd to claim that nationals of a given country pose a smaller health risk than other human beings, but this is the practical effect of biopolitical devices used. The pandemic acted like a trigger, unleashing sovereignty-oriented apparatuses of the state and producing a generalised state of exception (although not everywhere the eponymous legal device was officially used).

Therefore it is crucial to perceive the multifarious, but convergent trends in response to COVID as consisting of a few key elements that are structurally intertwined. First, there is a visible swerve towards priority of the executive. As noted by Elena Griglio, 'In Europe, executive dominance in policymaking is indisputably one of the effects of the spread of the pandemic.... The participation of parliaments in decision-making has been confined in scope-since many urgent governmental measures were adopted bypassing legislatures - and in their room for manoeuvre, since their legislative prerogatives were reduced to little more than ratifying executive proposals.' (Griglio 2020, 49-50). An analogical process took place in the EU (Griglio 2020, 50). This 'hour of the executive', as Tristan Barczak calls it (Barczak 2020), was - as usual - argued in terms of a necessity of a quick and pragmatic reaction that could not be taken by deliberative, in particular parliamentary bodies. The ability "to get things done" (Petrov 2020, 78) of the executive is its well-known aura that paves the way for extralegal measures legitimised directly - and in the atmosphere of tacit conjuration - by the objective that "must be reached".

Second, the role of the legislative was severely limited in two dimensions: first, the parliaments were truncated in order to reduce the spread of the virus amongst the deputies (Griglio 2020, 53-54; Bar-Siman-Tov 2020, 14-18), but even more importantly, as usual in exceptional times they were relegated to a subsidiary role of more or less tacit acceptants and occasional overseers of measures adopted by the executive (Griglio 2020, 52, 54; Barczak 2020; Petrov 2020, 72-79; Quintana, Uriburu 2020, 691). These restrictions were materialised with additional methods of surveillance used by governments (Borovitskaja 2020, 4). As in the case of Israeli Knesset, the organisation of parliaments under COVID 
also preferred their "executive" side: instead of a general freedom of expression, parliaments were monopolised by speakers, committees and party leaders (BarSiman-Tov 2020, 25-29; Cormacaina, Bar-Siman-Tov 2020, 9; Griglio 2020, 62). Rarely these measures were challenged in courts. In Israel, the Supreme Court ordered the parliament to reconvene, unleashing a constitutional crisis due to the disagreement of some representatives with the order (Bar-Siman-Tov 2020, 39). Only in Columbia a decree establishing the online parliamentary sessions was openly declared unconstitutional (Bar-Siman-Tov 2020, 17).

As noticed by Griglio, "executive dominance is not a novelty for representative democracies. In the last few decades, representative assemblies have been marginalised at least in their traditional role as legislators and decisionmakers" (Griglio 2020, 50). What Griglio describes is not far from Schmitt's pre-war analyses: it seems that "in the liberal legal order there is a kind of cyclicity, in which the period of decaying parliamentarism happens in purportedly 'golden' times of capitalist development, only to be revealed as already rotten when a crisis comes." In fact, the practical state of exception only reveals the hollowing out of democratic institutions that has been happening for a long time. In this vein, Schmitt's remarks only cast light on the ongoing process of deterioration that became visible when the state of exception formally came.

Accordingly, it should not be of any surprise what John Maxeiner noticed à propos the US legal system:

America's legal system as a system of laws is failing. America's responses to coronavirus have had more in common with a reign of men than with a government of laws. [...] Long before the coronavirus reached America's shores, the United States was falling short in fulfilling a rule of law. Instead of practicing the government of laws that its Founders sought, it has been suffering a government of men that they feared. (Maxeiner 2020, 215-216)

In case of the US, the imbalance between the executive and the legislative - as well as between the federal and state levels - are rooted in the inadequacies of the American constitution to present-day conditions (Maxeiner 2020, 232-233). But in other countries the pandemic revealed structural deficiencies of political and constitutional systems of their own. Constitutional states of exceptions were either modified by statutory laws (and subsequent ordinances) or ignored and replaced by sub-constitutional norms. Even in Germany, which might seem the closest to the Rechtsstaat-ideal, the three types of Notstandverfassungen contained in the Basic Law were found insufficient and a new law was adopted (Gesetz zum Schutz der Bevölkerung bei einer epidemischen Lage von nationaler Tragweite) to declare a special state of emergency - "the situation of epidemic of national scale" (Barczak 2020).

Another trait of pandemic governance was severe limitation of human rights, especially freedom of movement, right to privacy, religious freedoms and freedom of assembly (Quintana, Uriburu 2020, 691; Windholz 2020, 98-99). In the entire 
world millions of people were confined to their homes, with various kinds of restrictions adopted in order to control the freedom of movement (El Fakhry Tuttle 2020; Das Neves Gonçalves 2020, 4). Apart from the intrastate restrictions, cross-border travel was severely limited (Maxeiner 2020, 213), thereby producing a Panoptikon-like ideal of the nation-state: individuals of every nationality are securely locked in their countries and in their own homes. All those who did not fit into this 'neat' classification - stateless persons or foreigners, homeless individuals - were left stranded. Limitations to human rights were coupled with increased penal measures and, quite often, excessive fines (Windholz 2020, 99). Human beings as such - depending on the categories they belonged to - were turned into a threat; as Agamben noticed, the laws turned people into potential infectors:

Fatte le debite differenze, le recenti disposizioni (prese dal governo con dei decreti che ci piacerebbe sperare - ma è un'illusione - che non fossero confermati dal parlamento in leggi nei termini previsti) trasformano di fatto ogni individuo in un potenziale untore, esattamente come quelle sul terrorismo consideravano di fatto e di diritto ogni cittadino come un terrorista in potenza. (Agamben 2020b)

Finally, the role of the judiciary was effectively curbed. Only in few countries courts could play an active role in overseeing the exceptional measures adopted by the executive (or by the legislative acting upon the pressure of the executive). South Africa was a pioneer in this respect: by creating the post of COVID-19 Designate Judge (Petrov 2020, 80), it allowed a permanent monitoring of the emergency measures by a judicial mechanism - even if also 'executivised', that is reduced to one judge. Notably, the German Constitutional Court reacted to restrictions in the freedom of assembly, lifting the bans imposed on it (BVerfG, 29.04.2020, $1 \mathrm{BvQ} 44 / 20)$. The BVerfG argued that general restrictions on the freedom of assembly and religion are not proportionate to the pursued goal, and they need to be nuanced as well as allowing of exceptions. Generally, however, the response from courts was patchy and minimalistic (Petrov 2020, 89-91; Golia et al. 2020, 53), just as if - against their constitutional position - they did not want to provide a concerted response to exceptional measures.

These reactions of particular legal systems may be seen as necessary adaptations of legal instruments - by nature, slow and inert vis-à-vis reality - to the fast changes (cf. Flood 2020). But that is an easy track of interpretation which imagines necessity as coming entirely from the outside. What is much more interesting is to see that the model "fast changes - delayed response" is based on two tacit presuppositions: first, the external necessity does not gain this status until the legal system recognises it to have it, and second, the law has to react to the necessity and gain the upper hand in the struggle with it. In the next section I'll proceed to looking more closely into particular forms of the state of exception (or emergency) introduced in different countries: but regardless of a legal form in which exceptional measures were taken, the state of exception was 
preserved as the overarching framework of the law in its relation to reality (see also Agamben 2005, 40; 2012, 140-143; 2019, 50-51). The idea that the internal directives of the law (for example, constitutionally guaranteed rights or freedoms) may be ignored, if "necessity so demands", makes the category of necessity the Grundnorm of the legal system (thereby providing an obscene solution to the pre-war discussions between Kelsen and Schmitt). This feature may be called a generalised state of exception, transcending its particular incarnations in domestic legal system. In other words, the state of exception exists not only when a particular legal device of this name is triggered (be it a state of emergency or the "state of epidemic"), but when the legal system jumps ahead of its foundational regulations in order to establish exceptions (at any level) that correspond not to the official constitutional principles of a given order, but to the necessity itself, as recognised by the law.

The imbalance in the relations between the state powers in favour of the executive is a logical consequence of this generalised state of exception. It posits a chain of continuity between (legally established) necessity, exceptional measures, the executive and the inclusion/exclusion of human beings through the category of citizenship. What they all express is the ultimate grip of the law, which transcends all particular devices in which the relationship between the legal system and the reality is constructed.

\section{3. 'LIBERALISM'V. 'ILLIBERALISM': THE PANDEMICS TAKES IT ALL}

But does that mean that the establishment of exceptional measures within the boundaries of constitutionalism or outside of it is irrelevant? From the perspective of radical Agambenism, that seems to be the conclusion: no matter how the law attempts to regulate its relation to the necessity, it will be always excessive and unpredictable, so particular legal devices which are triggered do not matter. Yet this perspective is throwing the baby out with the bathwater: while the primacy of the generalised state of exception can be recognised universally, reactions of particular regimes differ. As if confirming the Luhmannian perspective on the autopoietic responses to the outside, every legal system - be it liberal or 'illiberal' (in the type proposed and propagated by Hungarian Prime Minister Viktor Orbán) - produces its own methods of addressing the necessity. Liberal reactions might preserve a bigger scope of individual freedoms, which is non-negligeable even in the context of generalised state of exception.

In the entire world, 96 countries declared some form of a state of emergency (COVID-19 Civic Freedom Tracker 2020; Bar-Siman-Tov 2020, 25). This makes the entire globe divided in half: the number of states that resorted to this device is almost equal to the number of those that did not. Naturally, one should not draw easy comparisons here: states of exceptions are not functional in all legal systems. 
The decision whether to adopt a state of emergency or not is not easily attributable to the position of a country vis-à-vis the axis 'liberalism - illiberalism' (dubious as it might seem in itself). In Europe itself there have been liberal countries that did not resort to the state of emergency (Italy), and illiberal ones that did (Hungary). Hungary is a special case due to its Enabling Act, widely seen as introducing a 'koronadiktatúra' (Petrov 2020, 72). Poland, which did not adopted any constitutionally envisaged exceptional measures, is a specific example of populist governmentality based on a vast scope of inapplicability of the law. It seems, however, that the decision whether to use the state of exception in any form is secondary: both the declaration of its state and its non-declaration may be used and abused by states. One could claim that declaring the state of exception is a better safeguard of legal standards and individual freedoms, but the existence of the generalised state of exception overwrites, at any rate, the formal legal devices that aim to contain it. As usual, the necessity forces special legislation which in itself has exceptional character, thereby exceeding the framework of the state of exception that has been declared. As argued by Angelo Golia et al.,

the measures adopted were, to a greater or lesser extent, "exceptional" from at least two points of view: first, several governments resorted to new or rarely used legal instruments, often outside of established emergency powers or emergency regimes; secondly, these measures as a whole have (or have had) the potential to trigger or accelerate broader institutional shifts or reconfigurations. Although the duration and intensity of these shifts remain difficult to predict, there remains the potential for the pandemic and the measures taken to respond to it to induce substantial changes to constitutional structures. (Golia et al. 2020, 1)

The process of the generalised state of exception taking over the particular states of emergency is visible in numerous states. The US declared a State of National Emergency in March 2020, but it needed to be supplemented both by legislation - economic "deal packages" - whose impenetrability and convolution pave the way for concealed exceptions (Maxeiner 2020, 217-222). But the state of emergency was additionally supplemented with two classes of acts: binding executive orders of the President and non-binding guidelines, both ridden with inconsistencies and contradictions (Maxeiner 2020, 222-224). The chaos was only aggravated with competition between states and their contradictory regulations (Maxeiner 2020, 227-231).

Germany declared its state of health emergency, but not a constitutional state of exception; the proposal to replace the parliament with a standing committee was not carried out (Golia et al. 2020, 15-16). Nonetheless, more exceptional measures were needed than those offered by the Infektionsschutzgesetz. Heads of Länder governments and the Chancellor needed to convene in an extraconstitutional format in order to exchange information on the measures they adopted (Barczak 2020). The effective state of emergency was a statutory, not constitutional measure (Golia et al. 2020, 33). Still, as it is claimed, the constitutional culture of Germany was strong enough to open a debate on the legality of the adopted measures: 
Besides these specific issues the first weeks of the pandemic also revealed much about German constitutional culture as a whole. This phase showed that German society has great respect for constitutional law, using it as a medium of reflection and a means of solving societal problems. The public debate regarding the COVID-19 measures was conducted in a highly legalistic manner and employed the categories of constitutional law. Significantly, for the most part these debates were carried out in the major daily newspapers as well as in online platforms such as the "Verfassungsblog". Nevertheless, this mode of reflection was not formalistic but extremely considered and responsive, impacting the choice of concrete measures. It allowed politicians to develop solutions that they would not have been able to reach without this reflection process. Consequently, the crisis has also revealed the degree to which constitutional law guides political processes in Germany. This close interaction with German constitutional law has probably contributed significantly to the successful management of the first weeks of the pandemic in Germany (Golia et al. 2020, 6).

France, by contrast, introduced state of emergency (état d'urgence sanitaire) quite quickly, with a clear swerve towards exceptional measures issued by the executive headed by the Prime Minister (Golia et al. 2020, 6, 24). This state was not constitutional, but based on statutory regulations and the doctrine of exceptional circumstances (Golia et al. 2020, 17). This choice proved controversial, as it required further statutory amendments to legalise the postponement of the second round of municipal elections, which would not need to happen if constitutional state of exception was declared (Golia et al. 2020, 17-18). Italy, which does not have a proper constitutional regime of the state of exception, needed to rely on particular constitutional devices, such as the possibility of issuing decreti-legge (Golia et al. 2020,18) 'in casi straordinari di necessità e di urgenza' (Art. 77 of the Italian Constitution), as well as on extraconstitutional administrative emergency instruments.

The distinction is, therefore, not necessarily between the countries that triggered constitutional states of exception and those that did not, but between the states that provided first a relatively coherent legal basis for future actions and those that acted patchily, without a coordinated legislative action, like Italy (Golia et al. 2020, 20-21). The same division cuts across 'illiberal' EU states. Hungary launched one of its constitutionally envisaged states of exception, namely the state of the danger of crisis, whereas the Polish ruling majority did not declare the state which the Constitution prescribed exactly for situations like pandemics, namely the state of national disaster (Drinóczi, Bień-Kacała 2020, 178). But the patterns of action after these initial choices did not run along the lines of constitutionality/unconstitutionality. In Hungary, the Authorisation Act was adopted in clear breach of the Fundamental Law insofar as it legalised the decrees that had been already issued and paved the way for adopting new ones outside of the scope of parliamentary control (Drinóczi, Bień-Kacała 2020, 
180). Poland declared a statutory state of emergency ("the state of epidemic"), only to adopt further anti-COVID measures by sub-statutory ordinances. Most conspicuously, prohibitions of movement, to all intents and purposes similar to curfews, were adopted on the basis of ordinances, in clear breach not only of the Constitution (Art. 52) and international law (Art. 5 ECHR among others), but even the statutory law in which they were allegedly grounded. Additional violations of the Polish constitution concern the illegal prohibition of the freedom of assembly, preparations for holding the presidential election via mail and, finally, postponing the election de facto without a constitutional mandate (Serowaniec, Witkowski 2020, 167-168; Drinóczi, Bień-Kacała 2020, 189-191). These measures demonstrate

how illiberal constitutionalism works: leaders are still pursuing their illiberal ideas and needs - which can more smoothly be achieved in the pretense of fighting against a human pandemic. Second, how emergency legislative drafting techniques can be 'illiberalized' - which, admittedly, follows from the logic of the regime. (Drinóczi and Bień-Kacała 2020, 191)

Consequently, if the COVID-related states of exception demonstrate any global trend, they seem to contribute to the age-old debate on the possibility of curbing the state of exception within boundaries of the law. First, constitutional devices of the state of exception proved inadequate in many countries, the necessity being of a radically new character. As a result, statutory regulations of medical emergency were often triggered. Secondly, even these measures proved inadequate and required partial adjustments, often adopted via ordinances or decrees issued by the executive. It is true that a good constitutional framework fares better in exceptional times (Drinóczi and Bień-Kacała 2020, 172), but it does not dismantle the generalised state of exception, which overwrites it with particular measures taken praeter or even contra legem.

\section{COVID-19 CLUB OF SOVEREIGNS}

The chain between the concepts of sovereignty, necessity and the executive - sealed by the generalised state of exception - is visible also on the international level. The national contraction made it problematic, with international institutions seeking legitimacy and influence by trying to help nation states in the pandemic. But international law has once again been revealed as an exclusive club of sovereigns. There are at least two dimensions of this process: international responsibility of states for spreading COVID and international human rights protection mechanisms that should intervene when human rights are endangered.

As far as the first issue is concerned, the rules on international responsibility of states (codified in the Draft Articles on Responsibility of States for Internationally Wrongful Acts), could allow to link the damages incurred by nations (financial 
losses, costs of shutdowns and lockdowns, healthcare expenses) with an internationally wrongful actions undertaken by China. It might seem reasonable that the state in which the pandemic originated - and which adopted a secretive policy that prevented other states taking the necessary precautions - be found internationally responsible. According to Art. 3 DARS, "The characterization of an act of a State as internationally wrongful is governed by international law. Such characterization is not affected by the characterization of the same act as lawful by internal law". It has been proposed that the legal act on which China's responsibility could be invoked are the International Health Regulations (IHR), a binding treaty approved by the WHO in 2005 and ratified by China (Mazzuoli 2020, 441). Article 7 IHR envisages that "If a State Party has evidence of an unexpected or unusual public health event within its territory, irrespective of origin or source, which may constitute a public health emergency of international concern, it shall provide to WHO all relevant public health information." This provision was clearly infringed by China in its non-dissemination policy (Mazzuoli 2020, 446-448). The trouble in demanding China's responsibility is expressed, however, in the following question: "how could it be possible to claim damage reparation from China if many states have not done their duty to take proper measures of restriction and social isolation?" (Mazzuoli 2020, 456). Collusion between sovereign states, which are not interested in displaying their own failures, is an effective obstacle to demanding actions from China on the basis of international law. Contrary to the claim frequently pronounced in the $90 \mathrm{~s}$, according to which we live in a post-Westphalian era, focused on the common interest of humankind rather than state interest, the pandemic clearly reveals the role of sovereigns in international law.

International law did not prove efficient at the level of international human rights protection mechanisms. If we take into account the European Convention on Human Rights - allegedly, the most developed instrument of human rights protection in the world - we will see that its reaction to the COVID is hampered by two crucial obstacles. First, Art. 15 allows of derogations of some ECHR articles in times of war or a threat to the life of the nation. This article functions as nothing less but a state of exception in its own right (Bachmann, Sanden 2020, 423). Ten countries invoked it in the period of the pandemic, usually derogating from the freedom of movement and assembly. More interestingly, these were the countries of Caucasus, South-Eastern Europe and two Baltic states; Western European countries did not resort to this measure, risking the future declarations of violations from the ECtHR if the measures they adopted were incompliant with limitation clauses of the Convention (Bachmann, Sanden 2020, 425-427). But even in case of the countries that did not use Art. 15, the scope of limitation clauses seems broad enough to encompass emergency measures (Dzehtsiarou 2020), turning them into 'micro-states of exception'. Second, by the delay in hearing cases by the Court - sometimes amounting up to 5 years - the states 
are given an effective carte blanche for here and now. This adds to the rule of the executive, which finds itself ahead not only of the legislative, but even more importantly, of international judiciary.

As a consequence, sovereign states remain key players in the field also on the international level. If, according to Schmitt, the state of exception allows us to recognise the true sovereign, it is a defence against external threat - framed in the concept of security - that gives this sovereign its popularly recognised legitimacy. International institutions were relegated to the subsidiary position by the pandemic; COVID-19 revealed that the states believe themselves to be the crucial actors whenever necessity is invoked and act accordingly. It could be therefore claimed that the generalised state of exception, having a foothold always on the domestic level, is potent enough not only to suspend or disregard constitutional norms, but also mechanisms of international law.

\section{CONCLUSIONS}

Whenever COVID-19 is presented as a catastrophe, it needs to be seen in a correct perspective. The pandemic - apart from being a medical calamity in itself - only revealed the contours of the politico-legal framework that organises a response to the threat. This framework is contradictory: nourished by withered imagery of triumphant liberalism of the $90 \mathrm{~s}$, it is in fact based on the hollowing out of democratic institutions caused by decades of turbocapitalism. Authoritarianism is the song of today, both of autocratic technocrats in power and of populist movements that attempt to combat globalisation with strengthening of statal apparatuses. We wake up today with the same realisation that Schmitt made in the interwar period: parliamentary democracy is severely weakened, and the pandemic coup de grâce only reveals that its functioning has never been properly based on a coherent legal order guaranteeing universal rights and freedoms.

The problem of historical repetitiveness adds to our position vis-à-vis the catastrophe: we perceive it with an inkling of how the situation might deteriorate. As in Benjamin's quip mentioned in the introduction, our tradition allows us to hear, but not see. We are perfectly able to understand how states of exception are constructed, executed and abused, yet the immediate perception of the catastrophe is shrouded by the thick fog of ideologemes describing COVID-19 as a chance to reconstruct capitalism, restore the nature and rebuild inter-individual relations. Against this Age-of-Aquarius-type of obscurantism (Das Neves Gonçalves 2020, 8, 12) we need to reaffirm the existence of the generalised state of exception that sustains the chain of other concepts: sovereignty, necessity and citizenship. What the pandemic demonstrated was a clear return to the sovereign logic, both on domestic and international levels. COVID-19 opened new-old paths 
of governing the living (Agamben 2020a) that will play a planetary role in the future fights for dominance and imposing a new face of capitalism. That is what our tradition allows us to hear; but seeing is another matter and it still seems that we are living in the margin that the catastrophe will soon cease to grant us.

\section{BIBLIOGRAPHY}

Agamben, Giorgio. 2005. State of Exception (Homo sacer II, 1). Translated by Kevin Attell. Chicago-London: The University of Chicago Press. https://doi.org/10.2307/j.ctv1134d6w.16

Agamben, Giorgio. 2012. Opus Dei. Archeologia dell'ufficio (Homo sacer II, 5). Torino: Bollati Bolinghieri.

Agamben, Giorgio. 2019. Creation and Anarchy. The Work of Art and the Religion of Capitalism. Translated by Adam Kotsko. Stanford CA: Stanford University Press. https://doi. org/10.1515/9781503609273

Agamben, Giorgio. 2020a. "Capitalismo comunista." Quodlibet, December 15, 2020. https://www. quodlibet.it/giorgio-agamben-capitalismo-comunista

Agamben, Giorgio. 2020b. "Contagio." Quodlibet, March 11, 2020. https:/www.quodlibet.it/ giorgio-agamben-contagio [Accessed: 17 June 2021].

Anderson, Benedict. 1991. Imagined Communities. Reflections on the Origin and Spread of Nationalism. London-New York: Verso.

Bachmann, Sascha-Dominik (Dov). Joachim Sanden. 2020. "State Responsibility for the (Public) Right to Health and Security in Times of COVID Pandemic A European Perspective." Indonesian Journal of International \& Comparative Law VII: 407-430.

Bar-Siman-Tov, Ittai. 2020. "COVID-19 meets politics: the novel coronavirus as a novel challenge for legislatures." The Theory and Practice of Legislation 8(1-2): 11-48. https://doi.org/10.10 80/20508840.2020.1800250

Barczak, Tristan. 2020. "La pandémie :« heure de l'exécutif »? Regard sur le droit d'exception de la République Fédérale d'Allemagne." Jus Politicum, November 19, 2020. http://blog. juspoliticum.com/2020/11/19/la-pandemie-heure-de-lexecutif-regard-sur-le-droit-dexceptionde-la-republique-federale-dallemagne-par-tristan-barczak/ [Accessed: 17 June 2021].

Benjamin, Walter. 1969a. "Some Reflections on Kafka." In Illuminations. 141-146. Translated by Harry Zorn. New York: Schocken Books.

Benjamin, Walter. 1969b. "Theses on the Philosophy of History." In Illuminations. 253-264. Translated by Harry Zorn. New York: Schocken Books.

Billig, Michael. 1995. Banal Nationalism. London: Sage.

Bohoslavsky, Juan Pablo. 2020. "COVID-19, the Economy and Human Rights." International Journal on Human Rights 30: 85-98.

Borovitskaja, Aleksandra. 2020. "COVID-19: Into The Inferno." Amsterdam Law Forum 12(3): 9-14. https://doi.org/10.37974/ALF.364

Cormacaina, Ronan. Ittai Bar-Siman-Tov. 2020. "Legislatures in the Time of Covid-19." The Theory and Practice of Legislation 8(1-2): 3-9. https://doi.org/10.1080/20508840.2020.1816017

COVID-19 Civic Freedom Tracker. 2020. https://www.icnl.org/covid19tracker [Accessed: 17 June 2021].

Drinóczi, Tímea. Agnieszka Bień-Kacała. 2020. "COVID-19 in Hungary and Poland: extraordinary situation and illiberal constitutionalism." The Theory and Practice of Legislation 8(1-2): 171-192. https://doi.org/10.1080/20508840.2020.1782109 
Dzehtsiarou, Kanstantsin. 2020. "COVID-19 and the European Convention on Human Rights." Strasbourg Observer, March 27, 2020. https://strasbourgobservers.com/2020/03/27/covid-19and-the-european-convention-on-human-rights/ [Accessed: 17 June 2021].

El Fakhry Tuttle, Myrna. 2020. "Freedom of Movement during COVID-19." LawNow Magazine, September 1, 2020. https://www.lawnow.org/freedom-of-movement-during-covid-19/

Flood, John. 2020. “John Flood's Random Academic Thoughts (RATs).” John Flood Blog, March 28, 2020. http://johnflood.blogspot.com/ [Accessed: 17 June 2021].

Golia, Angelo Jr. Laura Hering. Carolyn Moser. Tom Sparks. 2020. "Constitutions and Contagion. European Constitutional Systems and the COVID-19 Pandemic." MPIL Research Paper Series 42. https://doi.org/10.2139/ssrn.3727240

Griglio, Elena. 2020. "Parliamentary oversight under the COVID-19 emergency: striving against executive dominance.” The Theory and Practice of Legislation 8(1-2): 49-70. https://doi.org/ $10.1080 / 20508840.2020 .1789935$

Luhmann, Niklas. 2004. Law as a Social System. Translated by Klaus A. Ziegert. Oxford: Oxford University Press.

Maxeiner, James R. 2020. "America's COVID-19 preexisting vulnerability: a government of men, not laws." The Theory and Practice of Legislation 8(1-2): 213-235. https://doi.org/10.1080/2 0508840.2020 .1809173

Mazzuoli de Oliveira, Valerio. 2020. "State International Responsibility for Transnational Pandemics The Case of COVID-19 and The People's Republic of China." The Indonesian Journal of International \& Comparative Law 7: 431-468. https://doi.org/10.2139/ssrn.3584944

Das Neves Gonçalves, Everton. 2020. "Necessária transição planetária: (in) convenientes do COVID-19 para viabilizar a benfazeja colheita futura no Brasil e na comunidade internacional de estados." Revista Jurídica 2(59): 255-282. https://doi.org/10.21902/revistajur.2316-753X. $\mathrm{v} 2 \mathrm{i} 59.4091$

Petrov, Jan. 2020. "The COVID-19 emergency in the age of executive aggrandizement: what role for legislative and judicial checks?" The Theory and Practice of Legislation 8(1-2): 71-92. https://doi.org/10.1080/20508840.2020.1788232

Quintana, Francisco-José. Justina Uriburu. 2020. "Modest International Law: COVID-19, International Legal Responses, and Depoliticization." The American Journal of International Law 114(4): 687-696. https://doi.org/10.1017/ajil.2020.65

Schmitt, Carl. 1985. Political Theology. Four Chapters on the Concept of Sovereignty. Translated by George Schwab. Cambridge MA-London: The MIT Press.

Schmitt, Carl. 1988. The Crisis of Parliamentary Democracy. Translated by Ellen Kennedy. Cambridge MA-London: The MIT Press.

Serowaniec, Maciej.Zbigniew Witkowski. 2020. "Can legislative standards be subject to 'quarantine'? The functioning of the Tablet Sejm in Poland in the COVID-19 era." The Theory and Practice of Legislation 8(1-2): 155-170. https://doi.org/10.1080/20508840.2020.1805851

Windholz, Eric L. "Governing in a pandemic: from parliamentary sovereignty to autocratic technocracy." The Theory and Practice of Legislation 8(1-2): 93-113. https://doi.org/10.1080 /20508840.2020.1796047 